\title{
РИТОРИЗАЦЯ ПОЧАТКОВОЇ МОВНОЇ ОСВІТИ: ТЕОРЕТИЧНИЙ І ПРАКТИЧНИЙ ВИМІРИ
}

Poriadku orhanizatsii inkliuzyvnoho navchannia $\mathrm{u}$ zahalnoosvitnikh navchalnykh zakladakh" [Resolution of the Cabinet of Ministers of Ukraine of August 9, 2017, No. 588 "On Amendments to the Procedure for the Organization of Inclusive Education in General Educational Institutions"]. Available at: https:// zakon.rada.gov.ua/laws/show/588-2017-\%D0\%BF. [in Ukrainian].

5. Sadova, I. (2019). Osnovy defektolohii ta inkliuzyvnoi osvity: pidruchnyk [Fundamentals of Defectology and Inclusive Education: textbook]. Drohobych, 242 p. [in Ukrainian].

6. Sadova, I. (2019). Osnovy defektolohii ta inkliuzyvnoi osvity : materialy dlia praktychnykh zaniat i samostiinoi roboty : navchalnyi posibnyk [Fundamentals of defectology and inclusive education: materials for practical and independent work: teaching manual]. Drohobych, 44 p. [in Ukrainian].

Стаття надійшла до редакції 05.08.2019

УДК 372.881.116:808.5

DOI:

Світлана Яців, кандидат педагогічних наук, доиент кафедри англійської філології Прикарпатського національного університету імені Василя Стефаника

\section{РИТОРИЗАЦІЯ ПОЧАТКОВОЇ МОВНОЇ ОСВІТИ: ТЕОРЕТИЧНИЙ I ПРАКТИЧНИЙ ВИМІРИ}

У статті порушено проблему риторизачї початкової мовної освіти, проаналізовано шляхи ї̈ розв'язання, щзо передбачають навчання украӥнської мови та літературного читання у вимірах риторики. Результати дослідження засвідчили, щзо риторична підготовка учнів початкової школи здійснюється неефективно. Такі результати не можуть задовольнити сучасні вимоги, які ставить перед початковою ланкою освіти Нова українська школа, щзо робить необхідним упровадження процесу риторизації розроблення ефективної технології формування риторичної культури молодших школярів на уроках мовнолітературного циклу.

Ключові слова: риторизація; мовна освіта; молодший школяр; украйнська мова; літературне читання; риторична культура; риторична компетентність.

Jim. 5.

Svitlana Yatsiv, Ph.D.(Pedagogy), Associate Professor of the English Philology Department Vasyl Stefanyk Precarpathian National University

\section{RHETORIZATION OF ELEMENTARY LANGUAGE EDUCATION: THEORETICALAND PRACTICALASPECTS}

The article deals with a problem of rhetorization of elementary language education, the ways of its solution are analyzed, which include Ukrainian language teaching and literary reading in the dimensions of rhetoric. The results of the study showed that the rhetorical preparation of primary school students is ineffective. Such results do not meet current requirements of the New Ukrainian School before primary education, this makes necessary to introduce the process of rhetoric-the development of effective technology for the formation of the rhetorical culture of juniour students at the lessons of literary cycle. The rhetorical aspect of school language education has not been studied yet and requires research by scholars and teachers. Rhetorization of the language education in our understanding is a process of rethinking the purpose and content of school subjects 'Ukrainian language", 'Literary reading", priority of which is the formation of the rhetorical competence and the recognition and development of ways of organizing the educational communication in the communicative activity functionally and stylistically in aspects according to the laws of the rhetoric. Forming the rhetorical competence is a long painstaking process, so rhetorical personality education should be implemented at all levels, proceeding in several stages: propaedeutical (primary school), formative(secondary school),summarized systematically(high school), Academic High school, and improved by a person individually throughout his/her life. An urgent solution requires a problem of preparing primary school teachers for teaching this course, because rhetoric has its meaning and methods.

Keywords: rhetorization; language education; juniour students; Ukrainian language; literary reading; rhetorical culture; rthetorical competence.

П остановка проблеми у загальному вигляді. Сьогодні початкова освіта в Україні еволюціонує у напрямі риторизації навчального процесу: Нова українська школа спрямовує на комунікативно-діяльнісний підхід до вивчення навчальних предметів, закладаються методичні традиції розвитку риторичних здібностей молодших школярів. На 


\section{РИТОРИЗАЦИЯ ПОЧАТКОВОЇ МОВНОЇ ОСВІТИ: ТЕОРЕТИЧНИЙ ІПРАКТИЧНИЙ ВИМІРИ}

це орієнтують і основні освітні документи: Закон України "Про освіту" (2017р.), Закон України “Про вищу освіту” (2014 р.), Національна доктрина розвитку освіти України у ХХІ столітті, Концепція мовної освіти в Україні, Концепція навчання державної мови в школах України, Державний стандарт початкової загальної освіти та ін.

Актуальність проблеми риторизації мовної початкової освіти зумовлена потребою у формуванні творчої, гармонійно розвинутої особистості, здатної успішно комунікувати, ефективно володіти думкою, переконувати тощо. Саме в молодшому шкільному віці завдяки рідній мові відбувається становлення, розвиток, закріплення особистісних якостей дитини, формується іiі бачення навколишнього світу, культури мовлення і спілкування, розвиваються ії організаторські здібності, самостійна діяльність, образне і творче мислення тощо.

Аналіз останніх досліджень та публікацій. Проблема риторизацї шкільної освіти, формування риторично-комунікативних якостей дітей та юнацтва перебуває в центрі уваги педагогів, лінгвістів, методистів (Н. Бабич, Г. Білавич, А. Коваль, I. Кучеренко, Р. Лахманн, О. Когут, В. Нищета, М. Пентилюк, Г. Сагач, О. Сальнікова, І. Снігур, Н. Формановська та ін.). Активно досліджується роль риторико-мовленнєвого компонента в педагогічній діяльності вчителів загальноосвітніх шкіл, зокрема і початкових класів (І. Зязюн, Н. Ільїнська, А. Капська, Т. Петровська, Г. Сагач та ін.). Однак порушену в назві статті наукову проблему вчені всебічно не вивчали.

Мета статті - проаналізувати теоретичний та практичний аспекти проблеми риторизації початкової мовної освіти, означити шляхи підвищення рівня риторичної культури молодших школярів.

Виклад основного матеріалу. Результати аналізу наукових студій, присвячених порушеній проблемі, вивчення стану риторичної культури молодших учнів початкової школи засвідчили, що формування риторичної компетентності особистості школяра становить важливу проблему педагогічної науки, іiї розв'язання має велике науково-практичне значення для розроблення концептуальних положень з розвитку риторизації шкільної мовної освіти. Більш докладно зупинимося на окремих аспектах цієї складної педагогічної проблеми.

Насамперед на основі власних спостережень, результатів анкетування, проведеного в ІваноФранківських школах, стверджуємо про недостатній рівень комунікативної культури, риторичних умінь і навичок молодших школярів.
На жаль, і досі в освітньому просторі України не набула належного поширення практика вивчення риторики (ораторського мистецтва) як навчальної дисципліни в загальноосвітній школі. У багатьох початкових класах України $є$ пропедевтичний курс риторики (вивчається як дисципліна за вибором), для чого були створені відповідні програми та підручники з риторики для 1 - 4 класів (автори В. Науменко, М. Захарійчук). Цим надбанням може скористатися вчитель початкових класів, використовуючи на уроках української мови і літературного читання змістове наповнення підручників з риторики та структурні компоненти уроків риторики, які можна творчо адаптувати в процесі викладання рідної мови.

Окрім того, у теорії та практиці початкової ланки освіти ми виявили низку суперечностей між: вимогами навчальної програми початкової школи, згідно з якими мовлення учнів має бути точним, правильним, виразним із доречним уживанням виражальних засобів мови і мовленнєвого етикету, з одного боку, та низьким рівнем їхньої риторичної культури, з іншого; необхідністю проведення систематичної роботи з формування риторичнокомунікативних умінь учнів початкової школи під час опрацювання мовного матеріалу, літературних творів і в процесі спілкування, з одного боку, та відсутністю спеціальної методики 3 організації такого навчання, з іншого.

Тому на часі запровадження риторичного підходу до освітнього процесу, що пов'язано 3 явищем риторизації шкільної мовної освіти. Термін “риторизація” у цьому випадку співвідносимо 3 осмисленням і перетворенням характеру комунікативної діяльності у напрямі набуття i реалізації риторичних знань у процесі риторичної діяльності та іiі діалогізації, що, своєю чергою, передбачає формування риторичної культури тощо.

Риторична культура-це складне, багатоаспектне поняття, яке вчені співвідносять 3 поняттями комунікативної, мовної і мовленнєвої культури, риторичної і комунікативної компетентності тощо. Риторична культура пов'язана не тільки з умінням говорити, а й з уміннями впливати на розум, почуття і волю особистості. Це переконуюча комунікація. Риторична культура - складний, багатовимірний феноменом, інтегративна характеристика особистості школяра, яка включає сукупність засвоєних ним риторичних компетентностей та ціннісних норм риторичної діяльності, що, своєю чергою, передбачає індивідуально-творчий стиль ії реалізації. Відтак поняття “риторична компетентність" означає володіння риторичними знаннями, уміннями, 
навичками та якостями особистості, що визначають здатність і готовність до ефективного та оптимального спілкування. Вони реалізуються і закріплюються в досвіді комунікативнориторичної діяльності. Отже, риторична компетентність - це вищий рівень комунікативної компетентності. Цю компетентність в початковій ланці освіти покликані реалізувати предмети мовно-літературного циклу. Так визначає i Державний стандарт початкової освіти (лютий 2018 р.). Важливо підкреслити, що на першому місці “ключових компетентностей”, які мають бути сформовані в учнів початкової школи, $є$ “вільне володіння державною мовою”, ця навичка передбачає уміння усно та письмово висловлювати думки, почуття, чітко й аргументовано пояснювати факти. Шляхи i засоби досягнення цього завдання полягають у формуванні в учнів “любові до читання, відчуття краси слова, усвідомлення ролі мови для ефективного спілкування та культурного самовираження, готовність вживати українську мову як рідну в різних життєвих ситуаціях" [5].

Риторизація початкової мовної освіти складається 3 низки умовно виокремлених структурних компонентів: 1) теоретикопрактичного, що становить комплекс мовних і риторичних знань у контексті їхнього вправного застосування в мовленнєво-риторичній діяльності; 2) процесуально-діяльнісного (навички спілкування за певної ситуації для досягнення комунікативної мети); 3 ) морально-етичного (культурні, морально-етичні цінності та орієнтації особистості); 4) комунікативної активності, в основі якого лежить комунікабельність, тобто ініціативність, здатність і готовність школяра до свідомого самостійного включення в процес активного спілкування; 5) впливовості мовленнєвого акту (передбачає вправність у володінні експресивно-емоційними засобами мови для досягнення запланованого комунікаційного результату); 6) організаційно-методологічного (орієнтує на вправність у виборі стратегії і тактики спілкування) тощо $[1 ; 2 ; 3 ; 4]$.

Вважаємо, що риторичну культуру, риторичні вміння і риторичну компетентність необхідно розглядати як міжпредметні феномени, адже шкільна риторика дотична як до мовної, так і до літературної освіти. Мова та література як навчальні предмети мають багато спільного 3 погляду на їхній зміст (знання, текст, способи діяльності, досвід творчої діяльності, спілкування та ін.), виховне значення тощо.

Під риторизацією початкової мовної освіти розуміємо здійснення заходів на трьох рівнях: а) навчального процесу (педагогічне спілкування); б) української мови та літературного читання як складників загального процесу розвитку мовлення учнів; в) навчальних завдань, які конкретизують його зміст і завдання.

Уроки української мови та літературного читання мають значні потенційні можливості для вироблення і розвитку риторичних умінь молодших школярів, які в процесі ознайомлення 3 літературними творами набувають важливих комунікативних знань і навичок, ці уроки не тільки формують культуру мовлення, навички виразного читання, а й стимулюють уяву дітей, мотивують удосконалювати мовлення, розширюють когнітивні можливості, формують світогляд i моральні цінності, що є важливим ресурсом для повноцінного спілкування у різних комунікативних ситуаціях, формують риторичний досвід виступати публічно тощо $[1,7]$.

За результатами анкетування молодших школярів Івано-Франківських шкіл (було охоплено 120 учнів четвертого класу), 76\% юних респондентів зазначили, що відчувають страх перед публічним виступом, 89\% визнали себе “папірцевими ораторами”, 68\% осіб підкреслили, що недостатньо володіють риторичними вміннями, 94\% мовців не зважає на мовленнєві помилки, усі опитані молодші школярі зазначили, що хотіли б підвищити рівень риторичної культури та вивчати риторику. На запитання анкети “Чи достатній рівень риторичної культури мають учні Вашого класу?” відповіді вчителів-респондентів розподілилися так: “достатній” (31 \%), “середній” (46\%), “недостатній” (23\%).

Ключовою постаттю якісних змін в освітньому процесі початкової школи є добре підготовлений учитель. На жаль, не всі педагоги володіють достатніми знаннями для впровадження процесу риторизації початкової мовної освіти, необхідними навичками для формування комунікативної особистості молодшого школяра. Наведемо окремі результати опитування 20 вчителів початкової ланки освіти. Так, на запитання "Що ви вкладаєте у зміст поняття “риторичні вміння”?” педагоги дали відповіді, які групуємо у трьох варіантах: “правильне використання норм літературної мови, володіння необхідним словниковим запасом” (37 \%); “чітке і правильне висловлювання думки, уміння дискутувати, доводити свої погляди і переконання" (52 \%), 11 $\%$ респондентів наголосили на володінні знаннями мовного стилю і етикету; вихованні культури мовлення тощо.

Важливими для нас стали відповіді вчителів на три наступні запитання "Які, на Вашу думку, 
мають бути основні риси риторичної культури учнів?” (пропонувалося підкреслити такі варіанти відповідей: точність, логічність, змістовність висловлювань, ясність, чистота, виразність, нормативність, образність, багатство комунікативних засобів тощо): $52 \%$ вказали на всі ознаки, а $30 \%$ позначили одну-дві ознаки, 18\% вказали тільки на три-п'ять ознак.

Відповіді на запитання “Чи приділяєте Ви належну увагу формуванню риторичних умінь учнів на уроках української мови та літературного читання? Якщо приділяєте, то яким чином?” були такими: 28 \% опитаних відповіли, що роблять це систематично; $51 \%$ респондентів вказали, що роблять це “періодично”, а решта зізналися, що не приділяють спеціальної уваги цій проблемі. Більшість опитаних учителів намагаються на уроках стежити за виразністю і правильністю мовлення, навчають дітей використовувати формули мовленнєвого етикету, привчають будувати висловлювання грамотно, стежать, щоб учні правильно наголошували слова тощо.

Результати опитування показали, що більшість вчителів загалом розуміють необхідність риторизації початкової мовної освіти, важливість розвитку риторичних навичок молодших школярів, визнають значний потенціал української мови та літературного читання в цьому процесі. Однак частина 3 них розуміє риторичну культуру лише як володіння нормами літературного мовлення та не має чітких уявлень про особливості використання різних методів і форм роботи в цьому напрямі на уроках української мови та літературного читання. Педагоги певною мірою використовують риторичні поняття в навчальному процесі, однак зміст проаналізованих матеріалів дослідження, спостереження за діяльністю учителів окремих Івано-Франківських шкіл показують, що багато аспектів порушеної проблеми залишаються поза їхньою увагою. До прикладу, не завжди враховуються методичні особливості організації етапів роботи з художнім і власним текстами, методичні вимоги до добору художніх текстів, особливості вивчення напам'ять і читання творів та ін. Учителям не вистачає методичного забезпечення щодо використання елементів риторики під час уроків мовнолітературного циклу та позакласних заходів. Це засвідчує про відсутність або недостатнє опрацювання цих питань у теорії і шкільній практиці.

Отже, результати дослідження стану формування риторичної культури молодших школярів показало, що риторична підготовка учнів початкової школи здійснюється неефективно. Такі результати не можуть задовольнити сучасні вимоги, які ставить перед початковою ланкою освіти Нова українська школа, що робить необхідним упровадження процесу риторизаціїрозроблення ефективної технології формування риторичної культури молодших школярів на уроках мовно-літературного циклу. Окрім того, риторичний аспект шкільної мовної освіти донині цілком не вивчений, потребує дослідження i розроблення з боку науковців та вчителівпрактиків. Риторизація мовної освіти, у нашому розумінні, - це процес переосмислення мети та змісту шкільних предметів "Українська мова", “Літературне читання”, пріоритетним завданням яких $є$ формування риторичної компетентності, а також визначення і розроблення способів організації навчального спілкування в комунікативно-діяльнісному і функціональностилістичному аспектах та за законами риторики.

Формування риторичної компетентності тривалий і клопіткий процес, тому риторична освіта особистості має бути впроваджена на всіх рівнях, проходити у декілька етапів: пропедевтичному (початкова школа), формувальному (основна школа), узагальнювально-систематизувальному (старша школа), академічному (вища школа), а також удосконалюватися людиною впродовж усього життя. Нагального розв'язання потребує проблема методичної підготовки вчителя початкових класів до викладання предметів мовно-літературного циклу. $€$ підстави стверджувати про відсутність цілісного системного підходу в роботі над формуванням риторичної компетентності молодших школярів на уроках української мови та літературного читання.

Подальших досліджень потребує вивчення проблеми підготовки майбутніх учителів початкової школи до формування риторичної культури молодших школярів.

\section{ЛІТЕРАТУРА}

1. Білавич Г. Основи риторики і красномовства. Івано-Франківськ, 2016. 120 с

2. Бабич Н. Д. Лінгво-психологічні основи навчання і вивчення мови. Чернівці, 2000. 174 с.

3. Денисюк Л. Елементи риторики на уроках мови та літератури. Українська мова та література. 2002. № 13. С. 13-16.

4. Данильчук О., Тарасинська I. Програма 3 риторики. Дивослово. 2001. № 3. С. 34-36.

5. Державний стандарт початкової освіти. Затверджено постановою Кабінету Міністрів України від 21 лютого 2018 p. № 87. URL: https://www.kmu.gov.ua/ ua/npas/ pro-zatverdzhennya-derzhavnogo-standartupochatkovoyi-osviti

\section{REFERENSES}

1. Bilavych, H. (2016). Osnovy rytoryky i krasnomovstva 


\section{АНАЛІЗ ОСВІТНІХПРОГРАМ НАВЧАННЯ МАЙБУТНІХ ВЧИТЕЛІВ У КОНТЕКСТІ SТЕМ-ОСВІТИ}

[Basics of rhetoric and eloquence]. Ivano-Frankivsk, 120 p. [in Ukrainian].

2. Babych, N. D. (2000). Linhvo-psykholohichni osnovy navchannia $i$ vyvchennia movy [Linguistic and psychological basics of language teaching and learning]. Chernivtsi, 174 p. [in Ukrainian].

3. Denysiuk, L. (2002). Elementy rytoryky na urokakh movy ta literatury [Elements of rhetoric in language and literature lessons]. Ukrainian language and literature. No. 13, pp. 13-16. [in Ukrainian]
4. Danylchuk, O. \& Tarasynska, I. (2001). Prohrama z rytoryky [A rhetoric program]. Dyvoslovo. Vol. 3, pp. 3436. [in Ukrainian].

5. Derzhavnyi standart pochatkovoi osvity. Zatverdzheno postanovoiu Kabinetu Ministriv Ukrainy vid 21 liutoho 2018 r. № 87 [State standard of primary education .Approved by the Cabinet of Ministers of Ukraine resolution of February21,2018]. Available at: https://www.kmu.gov.ua/ ua/npas/ pro-zatverdzhennya-derzhavnogo-standartupochatkovoyi-osviti. (accessed10 Apr. 2019). [in Ukrainian].

Стаття надійшла до редакції 27.08.2019

УДК 37.091, 374

DOI:

Наталія Валько, кандидат фізико-математичних наук, доцент кафедри інформатики, програмної інженерії та економічної кібернетики Херсонського державного університету

\section{АНАЛІЗ ОСВІТНІХ ПРОГРАМ НАВЧАННЯ МАЙБУТНІХ ВЧИТЕЛІВ У КОНТЕКСТІ STЕМ-ОСВІТИ}

У роботі представлено аналіз освітніх програм підготовки вчителів природничо-математичних дисииплін закладів вищої освіти. Встановлено критерії сформованості STЕМ-культури майбутнього вчителя і умови в яких відбувається цей прочес. Сформульовані умови розвитку STЕМ-культури майбутнього вчителя природничо-математичних дисииплін. На основі аналізу зроблено кількісну очінку кредитів, які забезпечують предметну підготовку по кожному з напрямів: наука, технології, інженерія, математика. Визначено дисципліни, які впливають на розвиток STЕМ-культури майбутніх вчителів.

Ключові слова: STEM-освіта; STEM-навчання; освітні програми; міждисциплінарність; майбутні вчителі; природничо-математичні науки.

Puc. 1. Лim. 13.

Nataliya Valko, Ph.D.(Physical and Mathematical Sciences), Associate Professor of the Informatics,

Software Engineering and Economic Cybernetics Department Kherson State University

\section{AN ANALYSIS OF EDUCATIONAL PROGRAMS OF TRAINING OF FUTURE TEACHERS IN THE CONTEXT OF STEM-EDUCATION}

An analysis of training programs for teachers of natural and mathematical disciplines of higher educational institutions is presented in the work. The educational programs of specialties and certain disciplines that influence the development of STEM-culture of future teachers are analyzed. The article presents the determination of cognitive activity from a philosophical point of view that has allowed establishing the criteria for the formation of the future teacher and the conditions in which this process takes place. It also shows the influence of key competencies on the formation and development of STEM-culture of future specialists. The criteria for its formation are as follows: the independent definition of the teaching plan, the application of technological and innovative solutions to the problem solving, the ability to determine the trends of educational technologies, the involvement of students into research activities, the dissemination of innovation and knowledge about them. The conditions for the development of the STEM-culture of the future teacher of natural and mathematical disciplines are formulated: the presence of disciplines supporting innovative technologies and the content of which is based on the integration of scientific methods into the educational process, the presence of a professional community that is the center of innovation. An analysis of educational programs for the training of teachers of specialties "014 Secondary education", specialties "04 Mathematics", "08 Physics", "09 Informatics" and "15 Natural sciences" of the three institutions of higher education are presented. Quantitative assessment of educational credits, which provide subject preparation in each of the directions: science, technology, engineering, mathematics, is made. The disciplines that influence the development of STEM-culture of future teachers are determined.

Keywords: STEM-education; STEM-training; the educational programs; interdisciplinarity; pre-service teachers; natural sciences and mathematics.

П

остановка проблеми. Поява i

розвиток цифрових технологій

спричинили глобальні зміни і посилили значущість освіти у суспільному житті людини. На зміну постіндустріальному суспільству прийшло інформаційне, головними продуктами 